DOI: 10.18522/2073-6606-2016-14-2-100-109

\title{
OPTIMIZING ENERGY CONTRACTS FOR BUSINESS ENTERPRISES AND COMPANIES
}

\author{
Wadim STRIELKOWSKI, \\ PhD in Economics, Energy Policy Research Group, \\ University of Cambridge, \\ United Kingdom, \\ e-mail: w.strielkowski@jbs.cam.ac.uk;
}

Evgeny LISIN,

$\mathrm{PhD}$ in Economics, Associate Professor of the Department of Economics in Power Engineering and Industry, National Research University "Moscow Power Engineering Institute", Moscow, Russia, e-mail:lisinym@mpei.ru

Soaring electricity prices constitute a serious obstacle for both small and large business enterprises, since the costs of electricity are projected into the market prices of their goods and services. This paper analyzes the current conditions and offers some measures for optimization by the means of the parametric model that describes the conditions of power purchase agreements (PPA) for different groups of consumers with different demand profiles.

We use the case study of PPAs contracts in Moscow, the Russian capital, in order to model the optimal power supply for three hypothetical customers: a meat factory, a car wash, and an office unit. We employ a Heaviside step unit function in order to model the consumer demand and to calculate the gains for various types of consumers.

Our results demonstrate that consumers with higher energy consumption are better off when moving to across tariff zones changing the value of the contract. Moreover, it appears that changes into the investment policy of the hypothetical Russian enterprise enable it to lower the costs of energy and thence to increase the competitiveness of its good and services offered on the market. Our results might also be important in the context of the recent focus on the renewable energy and low-carbon future.

Keywords: electricity markets; consumers; tariffs; parametric model; optimization; Russian Federation

Acknowledgements: The paper was partially supported by the Ministry of Education and Science of the Russian Federation, research project No. 26.1795.2014/K

(С В. Стриелковски, Е. Лисин, 2016 


\title{
ОПТИМИЗАШИЯ КОНТРАКТОВ В ЭНЕРГЕТИЧЕСКОЙ ОТРАСАИ ААЯ БИЗНЕС-ПРЕАПРИЯТИЙ И КОМПАНИЙ
}

\begin{abstract}
В. СТРИЕЛКОВСКИ,
доктор экономических наук, научный сотрудник научно-исследовательской группы по проблемам энергетической политики, Кембриджская бизнес-школа, Кембриджский Университет,

Великобритания, e-mail: w.strielkowski@jbs.cam.ac.uk;
\end{abstract}

Е. Лисин,

кандидат экономических наук, доцент кафедры Экономики в энергетике и промышленности, Национальный исследовательский университет «Московский энергетический институт», Москва, Россия, e-mail: lisinym@mpei.ru

Резкий рост цен на электроэнергию представляет собой серьезное препятствие как для малых, так и для крупных бизнес-предприятий, так как затраты на электроэнергию закладываются в рыночную цену товаров и услуг этих предприятий. В данной работе представлен анализ текущих условий и предложены некоторые меры оптимизации посредством параметрической модели, описывающей условия заключения соглашений о закупке энергии (power purchase agreements, PРA) для разных групп потребителей, демонстрирующих различные потребительские профили.

В статье мы рассматриваем кейсы о заключении соглашений о закупке энергии в российской столице - Москве - с целью построения модели оптимальной передачи энергии для трех гипотетических потребителей: мясокомбината, автомойки и офисной компании. Мы используем функцию единичного скачка Хевисайда для моделирования потребительского спроса и расчета выгод для различных типов потребителей.

Результаты нашего исследования показали, что потребители с более высоким уровнем потребления энергии выигрывают, перемещаясь от одной тарифной зоны к другой, что влияет на ценность контракта. Более того, как оказалось, изменение инвестиционной политики гипотетического российского предприятия позволит ему снизить затраты энергии и в результате повысить конкурентоспособность своих товаров и услуг, предлагаемых на рынке. Результаты нашего исследования могут также иметь важное значение в контексте актуальности сегодняшней темы возобновляемых источников энергии и снижения уровня выбросов углерода для пользы будущих поколений.

Ключевые слова: рынки электроэнергии; потребители; тарифы; параметрическая модель; оптимизация; Российская Федерация

Благодарности: Статья подготовлена при частичной поддержке Министерства образования и науки Российской Федерации, научно-исследовательский проект № 26.1795.2014/K.

JEL classifications: Q40, Q41, L10, M20 


\section{Introduction}

Every business enterprise that uses the electrical energy as one of the inputs into its production process also needs to face a decision about how to shift its resources between energy bills and other production inputs. This task becomes very important with the recent focus on the renewables and renewable energy. One of the most effective options of how to optimize the excessive assets of a business company might be to invest them into the power supply contract with the purpose of creating a high advance payment for getting a positive economic effect from lower tariff (Amorim et al., 2013; or Bunn and Yusupov, 2015). Advance payment for the electricity depends on the power purchase agreement (PPA) contract and on the electricity tariff (see e.g. Strbac et al., 2014). If a business company increases the value of the contract agreement, it will get into the lower tariff zone and save on electricity bills (see e.g. Hwang and Lee, 2015). However, by doing so, it will also need to increase the amount of advance energy payments. The allocation of resources presents an optimization problem that can be often found in real life and in real businesses (see e.g. Beshkaret al., 2015; or Shieh,2015).

This paper attempts to optimize the parameters that influence the power supply contracts for different groups of consumers. This paper is structured as follows: Section 2 provides a short overview of the research literature on the topic. Section 3 presents the methods - i.e. calculating the number of hours of maximum power usage using the Heaviside step unit function. Section 4 explains the source and the scope of data used for our modelling. Section 5 outlines the main results of estimating optimal PPAs for different groups of consumers represented by the three types of businesses of a varying size. Finally, section 6 concludes with remarks and policy implications for the end business users as well as for the policy-makers and energy regulators.

\section{Literature review}

Different groups of consumers have different energy uptakes. It is therefore justified that each group should be charged differently. However, there are technological and social implications for this.

Schreiber et al. (2015) analyze flexible price signals that can act as effective demand control mechanisms. They show that different tariffs consist of combinations of flexible energy and power price signals and test their impact on the unit commitment of automatable for a set of German households. Their results suggest that flexible power pricing can reduce overall demand peaks as well as limit simultaneous grid withdrawals caused by real time pricing incentives while inefficient designs of flexible power pricing might lead to undesired bidding of automatable devices. A specific tariff design showing robust network performance and helping to reduce energy procurement costs might be a good solution to that.

One of the recently discussed cases for the different electricity residential tariffs is the case of the households with solar PV in Australia. For example, Simshauser (2016) describes a case of Southeast Queensland in Australia which has one of the highest penetration rates of domestic solar PV in the world. According to him, about $22 \%$ of households had PV in 2014 (and 75\% have air-con).Distribution charges in South Queensland are charged on the basis of $20 \%$ fixed cost and $80 \%$ per $\mathrm{kWh}$. The rapid increase in solar PV (from close to zero at the start of 2009) has resulted in a massive transfer of wealth and costs between customer groups. The results of the trial that included 6 digital meters installed in 69 broadly representative Queensland households at the customer switchboard circuit level separately measuring half-hour load for "general power" (e.g. fridge, tumble dryer, washing machine, toaster, kettle, clothes iron, computers, televisions, game consoles, etc.), air-conditioning, electric hot water systems, household lighting, oven and solar PV units were described by Simshauser (2016). Reported general power load accounted for $52 \%$ of household final demand, electric hot water represented $18 \%$, air-conditioning 
constituted 17\%, lighting consumed additional 10\%, and oven use was at 3\% (Simshauser, 2016). Electricity distribution network capacity is primarily driven by periodic demand, and household load generally peaks in the early evening, whereas solar PV production peaks during the middle of the day and thus a mismatch exists.

In a similar fashion, Bobinaite and Tarvydas (2014) use an example of renewable technologies in Lithuania to demonstrate that seeking to expedite solar sector development in Lithuania would require reviewing a feed-in tariff which currently is too low and impedes implementation of solar PV technologies. They point out that solar collectors in the country could compete in the district heating sector even without a support.

Yalcintas et al. (2015) look into a variety of pricing policies for commercial and industrial customer sectors using an example of two buildings foranalyzing energy usage under the uniform-rate and time-based pricing schedules of three electricity utilities. They show that critical-peak and real-time price signals encourage building caretakersto act in the aim of reducing their electricity costs. In the same time, consumption-shifting and energy savingwith regard to the time-based electricity prices do not appear to reduce energy usage and costs.

Overall, different examples and case studies from different corners of the globe demonstrate that consumers might benefit from moving across tariff zones and changing the value of their contracts. Changes into the investment policy and the power tariffs might significantly contribute to the prosperity and economic well-being.

\section{Methods and models}

When the PPA contract is set, the user sets up the contract value, e.g. the amount of $\mathrm{kWh}$ to be consumed on every month of a given year (Li et al., 2015). The values can be updated in accordance with the recent economic situation, the current state of enterprise's assets and the recent governmental policies and regulations.

On the basis of the contractual quantities set by business entities energy sales company issues a monthly bill to the customer, which is calculated as the product of the contract value and the price of electricity in the previous period. This price (tariff) might be different for various customers because it depends on voltage and on the number of hours of maximum power usage (HMU). The number of hours of maximum power usage is calculated as follows:

$$
H M U=C V_{\text {year }} / D P \text {, }
$$

where $C V_{\text {year }}$ is the annual contractual value and $\mathrm{DP}$ is the declared power.

Thence, according to the economic logic, the higher is the contractual value (either real or declared one), the higher is HMU. The interdependence between the tariff and the number of hours of maximum power usage (HMU) can be approximated by the Heaviside step unit function that takes up the following form:

$$
\theta(\mathrm{x}) \approx \frac{1}{2}+\frac{1}{2} t h k x=\frac{1}{1+e^{-2 k x}},
$$

where the parameter $\mathrm{k}$ determines the slope of the function.

The Heaviside step function is adiscontinuous functionwhosevalueiszerofornegativeargumentandoneforpositiveargument. It represents the general class of step functions and canberepresented as linear combinations of translations of Heaviside function(Xia et al., 2012). The Heaviside function is widely used in topology or project design but has also found its way into the economics and business, in particular when drawing the demand patterns of the market for electricity. Chart 1 shows the dynamics listing the changes in the tariff and the HMU.

Our calculations show that a customer can save by moving to the lower tariff through choosing the contract value that is higher than the actual consumption of electricity. By doing so, she will increase the HMU that will, in turn, allow her to get into lower tariff zone. 


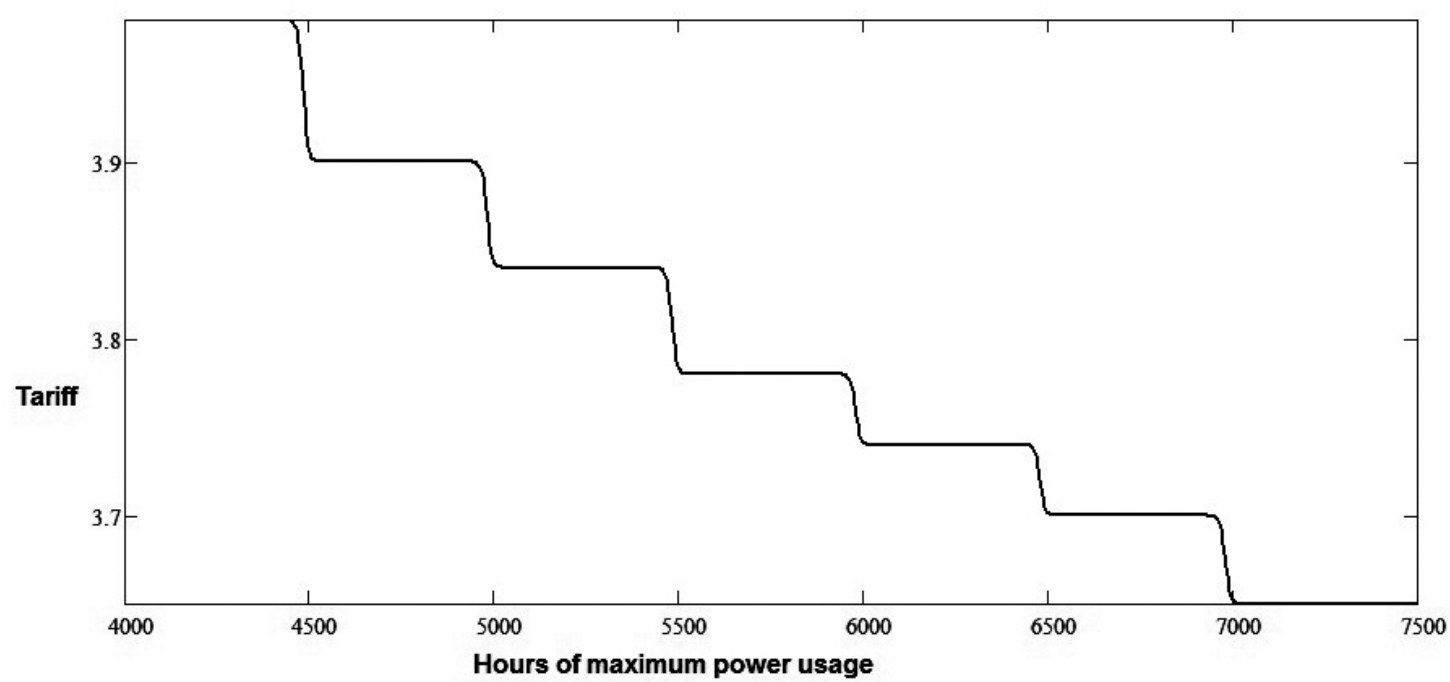

Chart 1. Interdependence between tariff and the HMU

Source: Own results

$E_{T}=A C\left(T_{a}-T_{c}\right)$,

where:

$E_{T}$ - representsmonetary saving from using a particular tariff,

$A C$ - is actual consumption,

$T_{a}$ - is the tariff that corresponds to the actual consumption,

$T_{c}^{a}$ - is the tariff that corresponds to the contract value

Our optimization problem is reduced to finding a contractual value at which the economic effect of investments in the energy supply contract will take the maximum value based on alternative investment funds. However, this methodology can also be applied to the other types of business contracts on the market (Ma et al., 2013).

\section{Description of data}

We obtained the data for the JSC "Mosenergosbyt" tariff network for various types of consumers.

Table 1

Low-voltage tariffs network

\begin{tabular}{|l|c|c|c|c|c|c|c|}
\hline $\begin{array}{c}\text { Period, } \\
\mathbf{2 0 1 1}\end{array}$ & \multicolumn{7}{|c|}{ Tariffs, rubles/kWh } \\
\cline { 2 - 8 } & $<4500$ & $\mathbf{4 5 0 1 - 5 0 0 0}$ & $\mathbf{5 0 0 1 - 5 5 0 0}$ & $\mathbf{5 5 0 1 - 6 0 0 0}$ & $\mathbf{6 0 0 1 - 6 5 0 0}$ & $\mathbf{6 5 0 1 - 7 0 0 0}$ & $\mathbf{7 0 0 0}<$ \\
\hline $1-11$ & 4,387593 & 4,293343 & 4,217433 & 4,154483 & 4,101663 & 4,056753 & 4,000453 \\
\hline $2-11$ & 4,433913 & 4,356243 & 4,293693 & 4,241833 & 4,198303 & 4,161293 & 4,114903 \\
\hline $3-11$ & 4,316183 & 4,236273 & 4,171913 & 4,118553 & 4,073773 & 4,035703 & 3,987973 \\
\hline $4-11$ & 4,380263 & 4,295633 & 4,227473 & 4,170963 & 4,123533 & 4,083203 & 4,032653 \\
\hline $5-11$ & 3,994133 & 3,919293 & 3,859023 & 3,809053 & 3,767113 & 3,731453 & 3,686753 \\
\hline $6-11$ & 4,058843 & 3,986803 & 3,928773 & 3,880663 & 3,840283 & 3,805953 & 3,762913 \\
\hline $7-11$ & 3,878643 & 3,822443 & 3,777183 & 3,739653 & 3,708153 & 3,681373 & 3,647803 \\
\hline $8-11$ & 3,868373 & 3,804843 & 3,753673 & 3,711243 & 3,675643 & 3,645363 & 3,607423 \\
\hline $9-11$ & 4,021883 & 3,946233 & 3,885313 & 3,834793 & 3,792403 & 3,756363 & 3,711173 \\
\hline $10-11$ & 4,029353 & 3,948063 & 3,882603 & 3,828323 & 3,782763 & 3,744033 & 3,695483 \\
\hline $11-11$ & 3,982363 & 3,901743 & 3,836823 & 3,782993 & 3,737813 & 3,699403 & 3,651253 \\
\hline
\end{tabular}

Source: Mosenergosbyt, 2011 
JSC "Mosenergosbyt" is one of the largest Russian generating companies with about $8 \%$ share in all electricity generated in the Russian Federation (Partsvaniya, 2012). In accordance with JSC "Mosenergosbyt" tariff network, higher HMU would provide more advantages to the customer (see Table 1).

For the sake of pursuing our approach and the method of modelling that it embeds, our data covers just the period of 2011. However, the time scope is not very relevant to the point that we are trying to make in this paper, since the division of business types into relevant groups that is based on this data represents a more valuable basis for the model. We used the data to construct three hypothetical consumers of electrical energy that are hereinafter tested for their implication with regard to various tariff zones.

\section{Results and discussions}

We run the models specified in equations 1-3 using the Mathlab software package environment. Table 2 shows the results for the three typical hypothetical types of business priced with different tariffs in JSC "Mosenergosbyt" tariff network.

Table 2

\section{Contract parameters for different groups of consumers}

\begin{tabular}{|l|c|c|c|}
\hline Type of business & $\begin{array}{c}\text { Declared power, } \\
\text { kW }\end{array}$ & $\begin{array}{c}\text { Annual contract } \\
\text { value } \mathbf{k W h}\end{array}$ & $\begin{array}{c}\text { Average (actual) annual } \\
\text { power usage kWh }\end{array}$ \\
\hline Meat factory & 300 & 920000 & 915000 \\
\hline Car wash & 82 & 278000 & 290000 \\
\hline Office unit & 12 & 12000 & 12300 \\
\hline
\end{tabular}

Our results clearly demonstrate that there are large energy consumers who benefit the most from changing the tariff to their convenience.

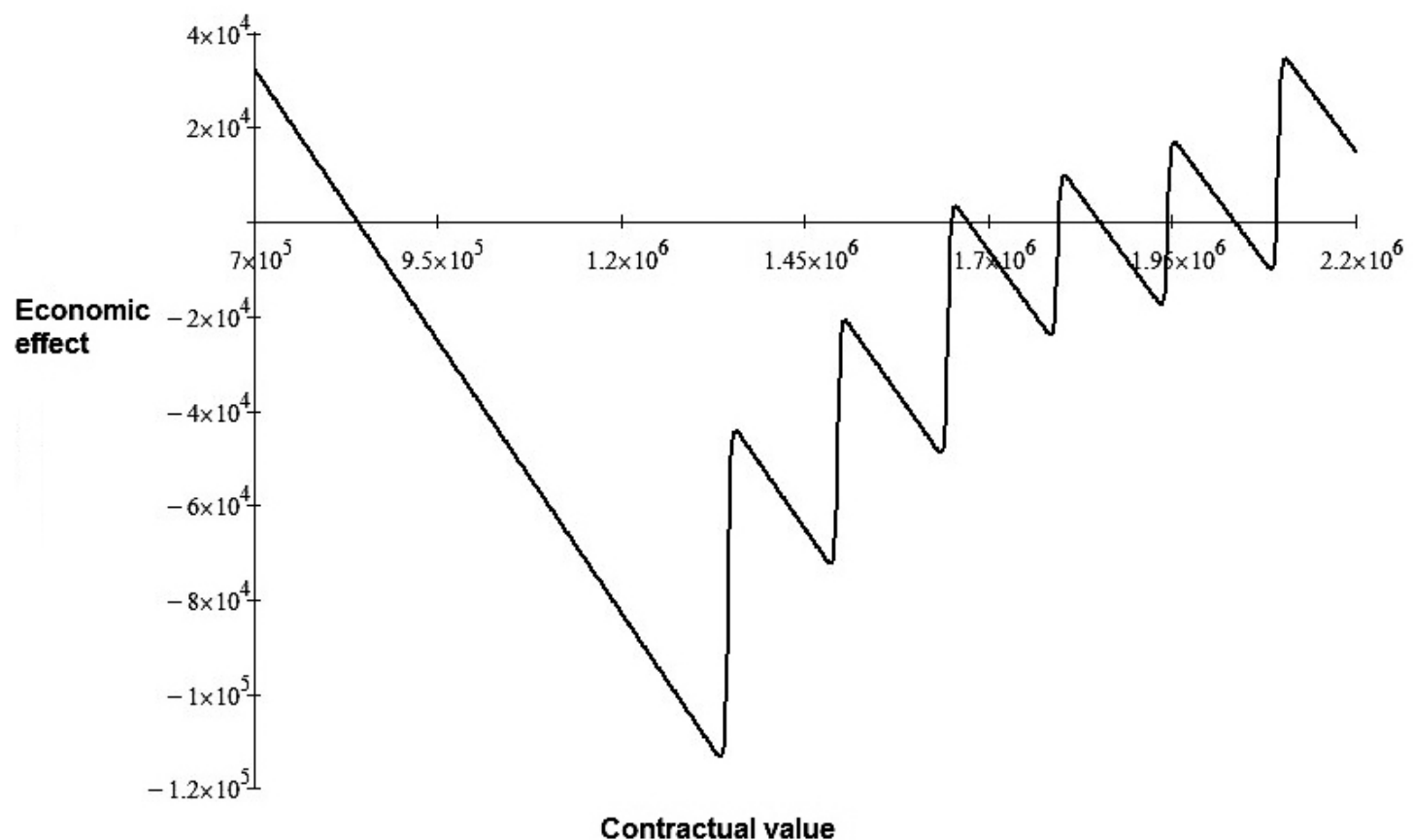

Chart 2. Dependence of economic effect on the contract value

Source: Own results 
Chart 2 depicted above shows the dependence of economic effect on the contract value. It becomes apparent that the economic effect gains positive values with the increasing value of the contract.

Table 3 shows the relationship between the tariff and the contractual value on the example of the large industrial consumer represented by the meat factory.

Table 3

Tariff and the contractual value for the sausage factory

\begin{tabular}{|c|c|}
\hline Contractual intervals, $\mathbf{k W h}$ & Tariff, rubles./kWh \\
\hline $0-1350000$ & 3,29 \\
\hline $1350000-1500000$ & 3,21 \\
\hline $1500000-1650000$ & 3,15 \\
\hline $1650000-1800000$ & 3,09 \\
\hline $1800000-1950000$ & 3,05 \\
\hline $1950000-2100000$ & 3,01 \\
\hline $2100000<$ & 2,96 \\
\hline
\end{tabular}

Source: Own results

Moreover, Chart 3 shows the dependence of rate of economic growth on the contract value. It corroborates the results that have been already plotted in Chart 2.

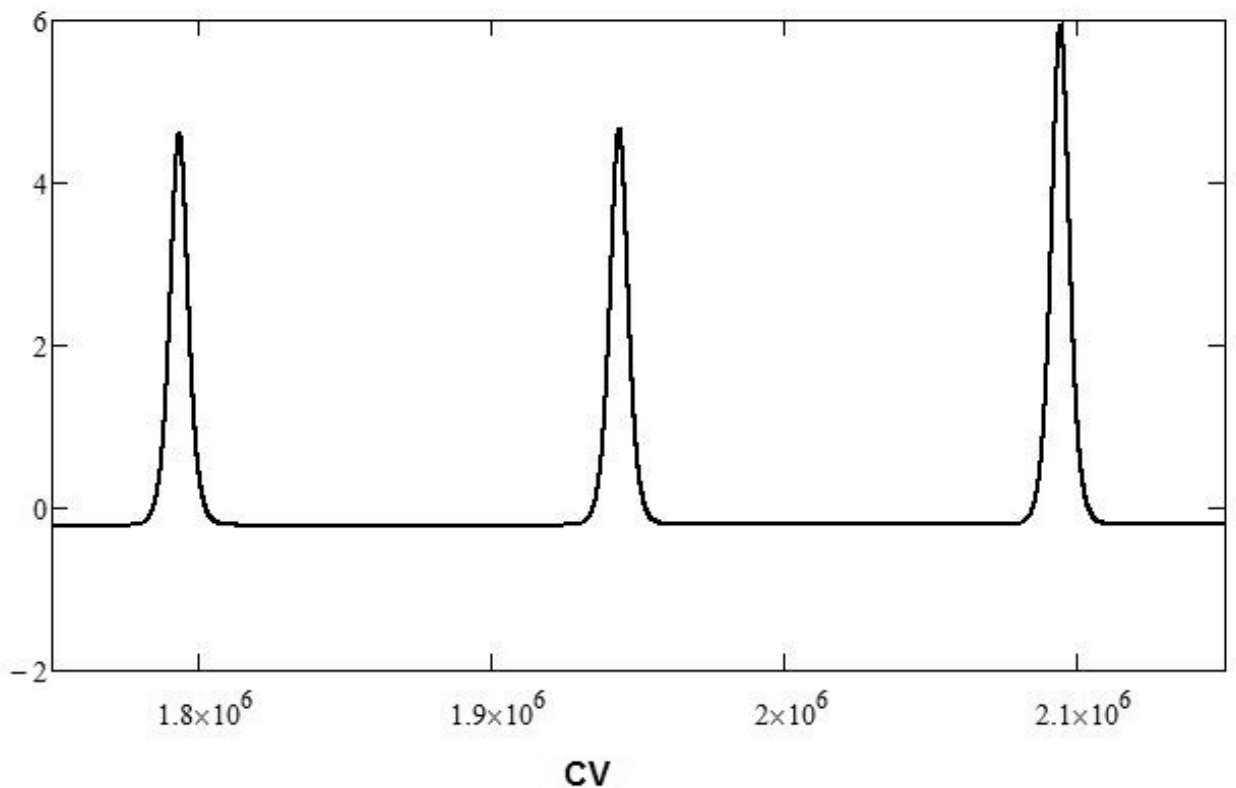

Chart 3. Dependence of rate of economic growth on the contract value Source: Own results

Similar to the sausage factory, the optimal economic outcomes can be calculated for the other two remaining types of business (Table 4).

It becomes apparent that there are higher economic gains for larger players on the market (large business enterprise represented in our model by the sausage factory) than for the smaller ones (an office unit) who are likely to be price-takers. 
Table 4

Economic effects for different groups of consumers

\begin{tabular}{|l|c|c|}
\hline Business type & Economic effect, rubles & Contract value, $\mathbf{k W h}$ \\
\hline Meat factory & 34000 & 2107000 \\
\hline Car wash & 15000 & 575000 \\
\hline Office unit & - & - \\
\hline
\end{tabular}

Source: Own results

\section{Conclusions}

All in all, it becomes obvious that it is beneficial for the business enterprise to be able to play with its energy tariffs by adjusting them with respect to their sizes and scopes. However, in the case of the small consumer that is represented in our framework by an office unit, it does not seem beneficial at all to increase the contractual value in order to get into lower tariff zone. This is due to the fact that the actual consumption for a given group of customers is small. Small consumers would be better off when directing their funds into alternative projects. It can be concluded that the proposed method of saving on a tariff is beneficial forthe consumers with higher power consumption.

Our results provide certain policy implications for both business owners and energy policy regulators: in case of business owners, it seems beneficial to let the companies to decide about their tariff zones. On the other hand, this cannot be abused, since smaller companies would carry the economic burden of paying higher electricity prices than the larger ones. This is where the energy policy regulators should step in and set up the rules for business companies to shift between tariff zones. Some time constraints or other regulations might be helpful in setting up the order on the electricity energy markets.

\section{JИTEPATYPA/REFERENCES}

Amorim F., Vasconcelos J., Abreu I.C., Silva P.D. and Martins V. (2013). How much room for a competitive electricity generation market in Portugal? //Renewable and Sustainable Energy Reviews, 18, pp. 103-118.

Beshkar M., Bond E.W. and Rho Y. (2015). Tariff binding and overhang: theory and evidence // Journal of International Economics, 97(1), pp. 1-13.

Bobinaite V. and Tarvydas D. (2014). Financing instruments and channels for the increasing production and consumption of renewable energy: Lithuanian case // Renewable and Sustainable Energy Reviews, 38, pp. 259-276.

Bunn D. and Yusupov T. (2015). The progressive inefficiency of replacing renewable obligation certificates with contracts-for-differences in the UK electricity market // Energy Policy, 82, pp. 298-309.

Hwang W.S. and Lee J.D. (2015). A CGE analysis for quantitative evaluation of electricity market changes // Energy Policy, 83, pp. 69-81.

Li Z., Ryan J.K., Shao L. and Sun D. (2015). Supply contract design for competing heterogeneous suppliers under asymmetric information // Production and Operations Management, 24(5), pp. 791-807.

Ma P., Wang H. and Shang J. (2013). Contract design for two-stage supply chain coordination: Integrating manufacturer-quality and retailer-marketing efforts // International Journal of Production Economics, 146(2), pp. 745-755.

Partsvaniya V.R. (2012). Management in Moscow energy system: Trends and optimization problems // Studies on Russian Economic Development, 23(2), pp. 145-152. 
Schreiber M., Wainstein M.E., Hochloff P. and Dargaville R. (2015). Flexible electricity tariffs: Power and energy price signals designed for a smarter grid //Energy, 93, pp. 2568-2581.

Shieh Y.N. (2015). A note on location and the output effect of ad-valorem taxes under free entry oligopoly // Economics and Business Letters, 4(1), pp. 30-35.

Simshauser P. (2016). Distribution network prices and solar PV: Resolving rate instability and wealth transfers through demand tariffs // Energy Economics, 54, pp. 108-122. Strbac G., Pollitt M., Konstantinidis C.V., Konstantelos I., Moreno R., Newbery D. and Green R. (2014). Electricity transmission arrangements in Great Britain: Time for change? // Energy Policy, 73, pp. 298-311.

Xia L., Zhu J. and Zhang W. (2012). Sensitivity analysis with the modified Heaviside function for the optimal layout design of multi-component systems //Computer Methods in Applied Mechanics and Engineering, 241, 142-154.

Yalcintas M., Hagen W.T. and Kaya A. (2015). Time-based electricity pricing for largevolume customers: A comparison of two buildings under tariff alternatives // Utilities Policy, 37, 58-68. 